\title{
Clinical Relevance of Serotonin Receptor Splice Variant Distribution in Human Colon
}

\author{
Moon Young Lee \\ Department of Physiology, Wonkwang Digestive Disease Research Institute and Institute of Wonkwang Medical Science, School of Medicine, \\ Wonkwang University, Iksan, Korea
}

Article: Distribution of $5-\mathrm{HT}_{3}, 5-\mathrm{HT}_{4}$, and $5-\mathrm{HT}_{7}$ receptors along the human colon

Yaakob NS, Chinkwo KA, Chetty N, Coupar IM, Irving HR

(J Neurogastroenterol Motil 2015;21:361-369)

The physiological effects of serotonin (5-HT) are exerted through the activation of various receptor subtypes that are classified into 7 dissimilar classes from $5-\mathrm{HT}_{1}$ to $5-\mathrm{HT}_{7}{ }^{1}$ Five of these classes $\left(5-\mathrm{HT}_{1}, 5-\mathrm{HT}_{2}, 5-\mathrm{HT}_{3}, 5-\mathrm{HT}_{4}\right.$, and $\left.5-\mathrm{HT}_{7}\right)$ have been found in the gastrointestinal (GI) tract. ${ }^{1}$ The suitability of the $5-\mathrm{HT}_{3}$ and $5-\mathrm{HT}_{4}$ receptors as therapeutic targets for management of functional GI disorder (FGID) has been investigated for clinical purposes. ${ }^{2}$ Recently $5 \mathrm{HT}_{7}$ has garnered attention as a possible therapeutic target. ${ }^{3,4}$

Owing to a lack of selectivity, however, administration of certain $5-\mathrm{HT}_{4}$ receptor agonists induced concomitant adverse cardiovascular events and so they were withdrawn from the worldwide market or restricted to emergency use. ${ }^{5} 5-\mathrm{HT}_{3}$ antagonists also have been principally limited to treating chemotherapy-induced nausea and vomiting and severe types of irritable bowel syndrome with diarrhea (IBS-D) due to side effects such as severe constipation and ischemic colitis. ${ }^{6}$ To minimize these undesirable side effects, the development of highly selective 5-HT receptor agonists/antagonists could be beneficial for clinical use. These agents would have a low risk profile, and there is the possibility that each of these agonists would have unique splice variants to address tissue-specific or disease-associated expression. ${ }^{5,7}$ Hence, more precise information concerning the expression level and spatial distribution of 5-HT receptor splice variants or isoforms throughout the human colon as well as the desensitization mechanism of the receptor will provide a better understanding of function and may offer new therapeutic views.

In the current issue of the Journal of Neurogastroenterology and Motility, an article entitled "Distribution of $5-\mathrm{HT}_{3}, 5-\mathrm{HT}_{4}$, and $5-\mathrm{HT}_{7}$ receptors along the human colon" aimed to examine the distribution of splice variants of $5-\mathrm{HT}_{3}, 5-\mathrm{HT}_{4}$, and $5-\mathrm{HT}_{7}$ receptors in different tissue layers at different regions of the normal human colon. ${ }^{8}$ They also described how this distribution is associated with receptor interacting proteins such as receptor interacting chaperone 3, G protein coupled receptor (GPCR) kinases (GRKs), and protein LIN-7 homologues to the length through

Received: June 1, 2015 Revised: June 20, 2015 Accepted: June 21, 2015

(c) This is an Open Access article distributed under the terms of the Creative Commons Attribution Non-Commercial License (http://creativecommons. org/licenses/by-nc/4.0) which permits unrestricted non-commercial use, distribution, and reproduction in any medium, provided the original work is properly cited.

${ }^{*}$ Correspondence: Moon Young Lee, MD, PhD Department of Physiology, Wonkwang Digestive Disease Research Institute and Institute of Wonkwang Medical Science, School of Medicine, Wonkwang University, Iksan 570-749, Korea

Tel: +82-63-850-6774, Fax: +82-63-852-6108, E-mail: Imy6774@wku.ac.kr

Financial support: This work was supported by Wonkwang University 2014.

Conflicts of interest: None. 
the human colon. ${ }^{8}$ This paper pioneers a comprehensive distribution analysis to elucidate the expression difference of specific splice variants between muscle and mucosa or the regional reliance between ascending, transverse, descending, sigmoid or rectum in the human colon by reverse transcriptase polymerase chain reaction (RT-PCR) and quantitative PCR (qPCR).

According to estimation from a large scale cDNA sequencing study in 10 diverse human tissues and 5 cell lines, 92-94\% of human genes are alternatively spliced. Indeed, various $5-\mathrm{HT}_{4}$ variants caused by alternative splicing of exons are widely distributed throughout the body and at this time, at least 11 human 5- $\mathrm{HT}_{4}$ receptor splice variants have been reported. ${ }^{3,4}$ Consistent with previous data, this study showed the dominant expression of $5-\mathrm{HT}_{4 \mathrm{a}}$ and $5-\mathrm{HT}_{4 \mathrm{~b}}$ in all tissue level including longitudinal, circular muscle and mucosa. The experiments also demonstrated that $5-\mathrm{HT}_{4 \mathrm{~d}}$ was expressed in all layers of tissue, albeit in a low number of patients. However, in contrast to the previous results, ${ }^{3}$ $5-\mathrm{HT}_{4 \mathrm{n}}$ and $5-\mathrm{HT}_{4 \mathrm{~g}}$ were highly expressed in the GI tract throughout all regions of the tissue. It has been suggested that most altered isoforms caused by differential splicing may show distinctive functional properties. ${ }^{10}$ In addition, it has previously been reported that changes to the splicing pattern could be associated with the disease state such as the exon switch of $\mathrm{CaV}_{1.2}$ transcripts in human vascular smooth muscle cells in atherosclerosis. ${ }^{11}$ Altered splicing patterns have also been associated with overexpression of $5-\mathrm{HT}_{4 \mathrm{~d}}$ with non-expression of $5-\mathrm{HT}_{4 \mathrm{a}}$ and $5-\mathrm{HT}_{4 \mathrm{~b}}$ in aldosterone-producing adenoma in comparison with normal adrenocortical tissues. ${ }^{12}$ Thus, it is possible that poorly expressed $5-\mathrm{HT}_{4}$ splice variants such as $5-\mathrm{HT}_{4 \mathrm{~d}}$ and $5-\mathrm{HT}_{4 \mathrm{~g}}$ can be changed toward the highly expressed state in some GI tract diseases, as the author proposed.

5- $\mathrm{HT}_{4}$ receptors are a member of GPCR, which have been considered the most highly encouraging class of drug targets in the present pharmacological approach., ${ }^{3,13}$ It has been demonstrated that desensitization rates of $5-\mathrm{HT}_{4}$ receptor splice variants depends on the GRK presence ${ }^{13}$ and on internalization of human $5-\mathrm{HT}_{4} \mathrm{R}$, which can occur in a splice variant specific manner. ${ }^{14}$ The major mechanism of desensitization for GPCR occurs through the GRKs-arrestin system. ${ }^{13}$ In this mechanism, GPCR can be desensitized by phosphorylation of GRKs with agonist activation. ${ }^{13}$ Phosphorylated receptors are in turn bound by arrestins, which inhibit additional stimulation of $G$ proteins and downstream signaling pathways. ${ }^{13}$ Previously it has been suggested that GRK2 and GRK6 may have an intricate relationship in the regulation of the desensitization of $5-\mathrm{HT}_{4}$ receptors in the distal colon. ${ }^{15}$ In this study, GRK6 showed more expression in the descending and sigmoid colon. This may imply regional differences of $5-\mathrm{HT}_{4}$ receptor desensitization in the human colon. Furthermore the functional diversity of $5-\mathrm{HT}_{4}$ splice variants could arise from the different $\mathrm{C}$-terminal interacting protein including $\mathrm{PDZ}$ domain based protein networks such as LIN7C, NHERF and SNX27. ${ }^{3,5}$ In this study, these proteins seemed to be expressed in all tissue levels. Therefore, it seems investigation of other protein candidates is needed.

So far five different $5-\mathrm{HT}_{3}$ subunits have been identified including $5-\mathrm{HT}_{3 \mathrm{~A}}, 5-\mathrm{HT}_{3 \mathrm{~B}}, 5-\mathrm{HT}_{3 \mathrm{C}}, 5-\mathrm{HT}_{3 \mathrm{D}}$, and $5-\mathrm{HT}_{3 \mathrm{E}}$ encoded by 5-HT type 3 receptor A subunit (HTR3A), HTR3B, HTR3C, HTR3D, and HTR3E genes, respectively. ${ }^{16}$ These subunits can form homomers or heteromers with the $5-\mathrm{HT}_{3 \mathrm{~A}}$ subunit and distributed in the human colon except $5-\mathrm{HT}_{3 \mathrm{D}}{ }^{4} \mathrm{In}$ the previous report, ${ }^{4}$ the authors suggested that $5-\mathrm{HT}_{3 \mathrm{~A} / 3 \mathrm{~B}}$ heteromer is more likely to form in the myenteric plexus and $5-\mathrm{HT}_{3 \mathrm{~A} / 3 \mathrm{E}}$ in the submucous plexus of the sigmoid colon, because $5-\mathrm{HT}_{3 \mathrm{~A}}$ was distributed throughout all colonic layers, whereas $5-\mathrm{HT}_{3 \mathrm{E}}$ was predominantly in the mucosa and $5-\mathrm{HT}_{3 \mathrm{~B}}$ in the muscularis. In the present study, however, only $5-\mathrm{HT}_{3 \mathrm{E}}$ showed significant increased expression in the mucosa. Considering HTR3E expression is uniquely restricted to colon and intestine through comparative expression analysis of all HTR3 genes, ${ }^{17} \mathrm{HTR} 3 \mathrm{E}$ and $5-\mathrm{HT}_{3 \mathrm{E}}$ subunit seems to be specifically expressed in the colonic mucosa. Mucosal $5-\mathrm{HT}_{3}$ receptor, which induces activation of extrinsic primary neurons, ${ }^{18}$ is involved the generation of pain symptoms. These symptoms can be prevented by administration of a $5-\mathrm{HT}_{3}$ antagonist in IBS. So if $5-\mathrm{HT}_{3 \mathrm{E}}$ is very specific for colonic mucosa, the development of this ligand will be a more effective target for treating the abdominal pain or discomfort in all types of IBS patients without undesired effects such as decreased transit or secretion in the small intestine and decreases in colonic compliance. In addition, it has been reported that $5-\mathrm{HT}_{3}$ receptor subunit alternatives by single nucleotide polymorphisms (SNPs) are linked with some clinical disorders, so some of $5-\mathrm{HT}_{3}$ subunits related to $\mathrm{SNPs}$ could be valuable biomarkers for drug selection. ${ }^{16}$

Like $5-\mathrm{HT}_{4}$ receptors, $5-\mathrm{HT}_{7}$ receptors are a member of GPCR and form multiple splice variants. $5 \mathrm{HT}_{7}$ receptors share an identical sequence up to Leu 432 and differ C-terminal with the PDZ C-terminal domain ligand binding site. ${ }^{3}$ Therefore $5-\mathrm{HT}_{7}$ may have similar characteristics with $5-\mathrm{HT}_{4}$ in terms of desensitization, internalization, trafficking and signaling. It has been proposed that abnormal stimulation of the $5-\mathrm{HT}_{7}$ receptor 
may contribute to IBS-like symptoms, so the $5-\mathrm{HT}_{7}$ receptor may be a reasonable therapeutic target in some FGIDs. ${ }^{19}$ In addition, it has been suggested that $5-\mathrm{HT}_{7 \mathrm{~d}}$ splice variant is expressed at relatively low levels in tissues such as the brain and spleen and is preferentially induced in the intestines, ${ }^{20}$ making it a suitable GI target. In this study, however, there was no distribution difference in the expression of $5-\mathrm{HT}_{7}$ receptor splice variants, although they were expressed in all tissue layers of the human colon. This inconsistency merits further study.

For an mRNA to be considered as a significant splice variant, there are several criteria recently suggested by Bonner. ${ }^{10}$ One of these criteria calls for the publication of a cDNA sequence corresponding to a functional protein domain in a public database. ${ }^{10}$ All of the human $5-\mathrm{HT}_{4}$ variants fulfill this criterion except 5- $\mathrm{HT}_{4 \mathrm{e}}$ and $5-\mathrm{HT}_{4 \mathrm{f} .}{ }^{10}$ More importantly, the second criterion specified by Bonner ${ }^{10}$ requires demonstration of a significant level of expression in some population of naturally occurring cells. Only 5-HT $\mathrm{Hb}_{4 \mathrm{~b}}$ fulfills this criterion. Besides the above 2 requirements, Bonner ${ }^{10}$ describes other criteria including evolutionary conservation between species, evidence of biological regulation, biochemically or pharmacologically different properties, and functional difference in naturally expressed variants. These other criteria have not yet been investigated for 5-HT splice variants, so it needs to be combed through the possible therapeutic 5-HT splice variants in the future.

There are some limitations in this study such as a small number of patients except the sigmoid colon cases, and the absence of qPCR results of $5-\mathrm{HT}_{4}$ splice variants. Unfortunately, the genes of receptors and ion channels are present at too low a level to measure in the tissue, so there is very little quantitative data concerning expression levels of these receptors in human tissues except $5-\mathrm{HT}_{4 \mathrm{~b}}$ splice variant. ${ }^{10}$

In conclusion, it is possible that different 5-HT receptor splice variants can be expressed in different regions; in turn they regulate the GI motility, sensory and secretomotor function in diverse modes. Therefore, this new approach to understand the distribution, desensitization mechanism and functional differences between 5-HT splice variants in the GI tract could lead to improved target-specific drugs in regards to safety, higher effectiveness and better tolerance.

\section{Acknowledgements}

The author thanks Robert Fuchs working in University of
Nevada for improving the readability of this manuscript.

\section{References}

1. De Maeyer JH1, Lefebvre RA, Schuurkes JA. 5-HT4 receptor agonists: similar but not the same. Neurogastroenterol Motil 2008;20: 99-112.

2. Fayyaz M, Lackner JM. Serotonin receptor modulators in the treatment of irritable bowel syndrome. Ther Clin Risk Manag 2008;4: 41-48.

3. Coupar IM, Desmond PV, Irving HR. Human 5- $\mathrm{HT}_{4}$ and $5-\mathrm{HT}_{7}$ receptor splice variants: are they important? Curr Neuropharmacol 2007;5:224-231.

4. Chetty N, Coupar IM, Tan YY, Desmond PV, Irving HR. Distribution of serotonin receptors and interacting proteins in the human sigmoid colon. Neurogastroenterol Motil 2009;21:551-558, e14-e15.

5. Tack J, Becher A, Mulligan C, Johnson DA. Systematic review: the burden of disruptive gastro-oesophageal reflux disease on health-related quality of life. Aliment Pharmacol Ther 2012;35:1257-1266.

6. Beattie DT, Smith JA. Serotonin pharmacology in the gastrointestinal tract: a review. Naunyn Schmiedebergs Arch Pharmacol 2008;377:181-203.

7. Bender E, Pindon A, van Oers I, et al. Structure of the human serotonin $5-\mathrm{HT}_{4}$ receptor gene and cloning of a novel $5-\mathrm{HT}_{4}$ splice variant. J Neurochem 2000;74:478-489.

8. Yaakob NS, Chinkwo KA, Chetty N, Coupar IM, Irving HR. Distribution of $5-\mathrm{HT}_{3}, 5-\mathrm{HT}_{4}$, and $5-\mathrm{HT}_{7}$ receptors along the human colon. J Neurogastroenterol Motil 2015;21:361-369.

9. Wang ET, Sandberg R, Luo S, et al. Alternative isoform regulation in human tissue transcriptomes. Nature 2008;456:470-476.

10. Bonner TI. Should pharmacologists care about alternative splicing? IUPHAR Review 4. Br J Pharmacol 2014;171:1231-1240.

11. Tiwari S, Zhang Y, Heller J, Abernethy DR, Soldatov NM. Atherosclerosis-related molecular alteration of the human $\mathrm{CaV} 1.2$ calcium channel $\alpha 1 \mathrm{C}$ subunit. Proc Natl Acad Sci USA 2006;103: 17024-17029.

12. Cartier D, Jégou S, Parmentier F, et al. Expression profile of seroto$\operatorname{nin} 4\left(5-\mathrm{HT}_{4}\right)$ receptors in adrenocortical aldosterone-producing adenomas. Eur J Endocrinol 2005;153:939-947.

13. Gainetdinov RR, Premont RT, Bohn LM, Lefkowitz RJ, Caron MG. Desensitization of $G$ protein-coupled receptors and neuronal functions. Annu Rev Neurosci 2004;27:107-144.

14. Pindon A, Van Hecke G, Josson K, et al. Internalization of human $5-\mathrm{HT}_{4 \mathrm{a}}$ and $5-\mathrm{HT}_{4 \mathrm{~b}}$ receptors is splice variant dependent. Biosci Rep 2004;24:215-223.

15. Nedi T, White PJ, Coupar IM, Irving HR. Tissue dependent differences in G-protein coupled receptor kinases associated with 5- $\mathrm{HT}_{4}$ receptordesensitization in the rat gastro-intestinal tract. Biochem Pharmacol 2011;81:123-133.

16. Yaakob N, Malone DT, Exintaris B, Irving HR. Heterogeneity amongst 5- $\mathrm{HT}_{3}$ receptor subunits: is this significant? Curr Mol Med 2011;11:57-68.

17. Niesler B, Frank B, Kapeller J, Rappold GA. Cloning, physical mapping and expression analysis of the human $5-\mathrm{HT}_{3}$ serotonin receptor-like genes HTR3C, HTR3D and HTR3E. Gene 2003;310: 
101-111.

18. Gershon MD. Nerves, reflexes, and the enteric nervous system: pathogenesis of the irritable bowel syndrome. J Clin Gastroenterol 2005;39(5 suppl 3):S184-S193.

19. Tonini M, Vicini $\mathrm{R}$, Cervio $\mathrm{E}$, et al. 5- $\mathrm{HT}_{7}$ receptors modulate peristalsis and accommodation in the guinea pig ileum. Gastroenterology
2005;129:1557-1566.

20. Krobert KA, Bach T, Syversveen T, Kvingedal AM, Levy FO. The cloned human $5-\mathrm{HT}_{7}$ receptor splice variants: a comparative characterization of their pharmacology, function and distribution. Naunyn Schmiedebergs Arch Pharmacol 2001;363:620-632. 